\title{
Impact of Tridax procumbens on Hematological Parameters in aflatoxin Induced Liver Toxicity in Albino Rats
}

\author{
Palanisamy Sampathkumar ${ }^{1}$, Subramanian Kalavathy² ${ }^{2}$, Arumugam Vijaya Anand ${ }^{3}$, Thangavelu Sangeetha ${ }^{3}$ \\ Purusothaman Sujeetha ${ }^{3}$
}

\section{Palanisamy \\ Sampathkumar', Subramanian Kalavathy ${ }^{2}$, Arumugam Vijaya Anand ${ }^{3}$, Thangavelu Sangeetha ${ }^{3}$ Purusothaman Sujeetha ${ }^{3}$}

\section{'Department of Chemistry and Biosciences, SASTRA Deemed University, Srinivasa Ramanujan Centre, Kumbako- nam, Tamil Nadu, INDIA. \\ ${ }^{2}$ Department of Botany, Bishop Heber College,Thiruchirappalli,Tamil Nadu, INDIA. \\ ${ }^{3}$ Department of Human Genetics and Molecular Biology, Bharathiar University, Coimbatore,Tamil Nadu, INDIA.}

\section{Correspondence}

Palanisamy Sampathkumar

Department of Chemistry and Biosciences, SASTRA Deemed University, Srinivasa Ramanujan Centre, Kumbakonam campus, Tamil Nadu, INDIA.

Phone no: +919842525830

E-mail: avamiet@yahoo.com

History

- Submission Date: 03-10-2017;

- Review completed: 20-11-2017:

- Accepted Date: 19-12-2017

DOI : 10.5530/pj.2018.2.53

Article Available online

http://www.phcogj.com/v10/i2

Copyright

(C) 2018 Phcog.Net. This is an openaccess article distributed under the terms of the Creative Commons Attribution 4.0 International license.

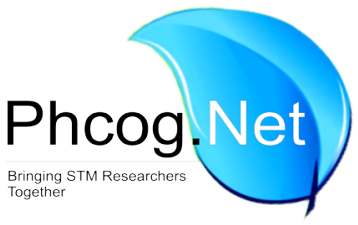

\begin{abstract}
Objective: Tridax procumbens comes under the family Asteraceae Tridax which is found to have anti-inflammatory, analgesic properties. Materials and Methods: The morphological parameters such as the body weight, liver and kidney weight of experimental animals which were fed by alfatoxin and thereby treating with extracts of T. procumbens were studied along with the Hematological parameters such as Haemoglobin (Hb), Red Blood Corpus Cells (RBC), White Blood Corpus Cells (WBC), Packed Cell Volume (PCV) and Prothrombin time (PT). Results: The results of this study shows that there is an significant changes in the body weight liver and kidney weight in T. procumbens treated animals and also significant raise in blood level was seen in the T. procumbens treated animals. Conclusion: Based on the results obtained, we concluded that T. procumbens have an antiaflatoxicosis potency.

Key words: Tridax procumbens, alfatoxin, Haemoglobin, Red blood corpus cells, White blood corpus cells, Packed cell volume, Prothrombin time, etc.
\end{abstract}

\section{INTRODUCTION}

In the system of Ayurveda medicine, the herbal plants and their extracts are used in the treatment of certain diseases. T. procumbens is the species of Tridax family which is found to have anti-inflammatory and analgesic properties. ${ }^{1,2,3}$ This plant and its extracts are commonly used in Ayurvedic medicine as anticoagulant, hair tonic, antifungal and insect repellent to treat bronchial catarrh, diarrhoea, dysentery, and in wound healing process. The objective of the study is to find out the changes in organ (Liver and Kidney) and body weight of the experimental animals on treating them with extracts of $T$. procumbens in alfatoxin fed experimental animals. The experimental rats were treated with aflatoxin along with tannin and sylimarin. These experimental animals showed changes in morphology parameters. The hematological parameters were also recorded along with the above mentioned morphological changes in those experimental rats.

\section{MATERIALS AND METHODS}

\section{Animals}

Male albino wister rats weighing about 125 to $150 \mathrm{~g}$ (45-60 days old) were purchased from Tamilnadu Veterinary University, Madhavaram, Chennai and maintained under standard experimental conditions (Temperature $27^{\circ} \pm 2^{\circ} \mathrm{C}$, relative humidity $60 \pm 5 \%$ and $12 \mathrm{~h} \mathrm{light/dark}$ cycle) in the animal house of Periyar Maniyammai College of Pharmaceutical Sciences, Tiruchirapalli. They were fed with pelleted diet manufactured by $\mathrm{M} / \mathrm{s}$ Hindustan Foods Limited, Bangalore, India and had free access to water ad libitum. Before the commencement of actual experiment the rats were acclimatized in the above condition for 15 days.

Toxin

\section{Production of aflatoxin}

Aspergillus parasiticus 'NRRL-2000' obtained from Central Clinical lab, Madras Veterinary College, Chennai was used as a source of inoculum for the production of aflatoxin. The fungus was maintained by sub culturing it on Potato-Dextrose-Agar slands. ${ }^{4}$ $50 \mathrm{~g}$ of raw rice was taken in $250 \mathrm{ml}$ conical flasks. After adding $25 \mathrm{ml}$ of water, the mixture was allowed to stand for 2 hours with frequent shaking. The flasks were autoclaved at 15 psi. for $15 \mathrm{~min}$, cooled and inoculated with spores of $A$. parasiticus 'NRRL2000'. The flasks were kept at room temperature in slanting position in a dark humid place and vigorously hand shaken six to ten times a day to avoid clumping. After 10 days of post-inoculation, the contaminated rice was treated in a steam bath for 5 min to arrest further growth of fungus and aflatoxin production. The rice was dried overnight at $60^{\circ} \mathrm{C}$ in a hot air oven. The mouldy rice was powdered and the quantity of aflatoxin content was estimated.

Cite this article: Sampathkumar $P$, Kalavathy $S$, Anand $A V$, Sangeetha $T$, Sujeetha $P$. Impact of Tridax procumbens on Hematological Parameters in Aflotoxin Induced Liver Toxicity in Albino Rats. Pharmacog J. 2018;10(2):304-8. 


\section{Estimation of Aflatoxin $B_{1}$}

Quantitative measurement of aflatoxin $B_{1}$ in mouldy rice was done as per the method of Romer. ${ }^{5}$ Slurry was prepared by blending $50 \mathrm{gm}$ of mouldy rice powder with $250 \mathrm{ml}$ of water. The extraction was done by blending 150 gm of slurry with $250 \mathrm{ml}$ of acetone for two min and filtered through Whatman No.1 filter paper. The extract was purified by taking $150 \mathrm{ml}$ of the extract in $500 \mathrm{ml}$ of conical flask and swirling it after adding $3 \mathrm{~g}$ of cupric carbonate. In another $500 \mathrm{ml}$ conical flask ferric gel was prepared by adding $30 \mathrm{ml}$ of ferric chloride solution $(0.41 \mathrm{M})$ to $170 \mathrm{ml}$ of sodium hydroxide $(0.2 \mathrm{M})$ and swirled. The ferric gel was immediately transferred to the flask containing the extract and the contents were mixed thoroughly and was allowed to stand for $2 \mathrm{~min}$. It was filtered through Whatman No.1 filter paper and $100 \mathrm{ml}$ of filtrate was mixed with $100 \mathrm{ml}$ of $0.03 \%$ sulphuric acid in $500 \mathrm{ml}$ separating funnel and the extraction was done thrice using $20 \mathrm{ml}, 20 \mathrm{ml}$ and $10 \mathrm{ml}$ of chloroform respectively and each time the lower chloroform layer was collected. The combined extract was transferred to a $250 \mathrm{ml}$ separating funnel containing a mixture of $100 \mathrm{ml}$ of $0.02 \mathrm{M}$ potassium hydroxide, $1 \%$ potassium chloride mixture and gently swirled for $10 \mathrm{sec}$. The lower chloroform layer was collected in a $100 \mathrm{ml}$ beaker through a funnel containing a bed of anhydrous sodium sulphate. The final extract was evaporated to near dryness in a water bath at $40^{\circ} \mathrm{C}$ and transferred to a vial and dried completely. Known quantity of chloroform was added to dilute the extract and subjected to thin layer chromatograph (TLC) for quantification. The TLC plates were prepared ( $0.25 \mathrm{~mm}$ thickness) by using silica gel G: water (2:1) slurry and activated at $110^{\circ} \mathrm{C}$ for an h. Pure aflatoxin $B_{1}$ obtained from MLS Sigma chemicals, USA, was used as the standard. The samples and standards were spotted on the TLC plates and developed in Chloroform:Acetone (9:1) mixture for $45 \mathrm{~min}$. The developed plates were compared under long wave UV lamp in a chromato view cabinet. The aflatoxin $\mathrm{B}_{1}$ content was calculated according to AOAC (1990) specification.

\section{Dosage}

It is clear that for short duration single administration studies, higher dosages are used. For prolonged administration (30 days) the concentration of toxin is low. Hence for the present study of 30 days duration, $1 \mathrm{ppm}$ concentration of the toxin along with the diet has been fixed.

\section{Drugs}

T. procumbens

Fresh leaves of T. procumbens were collected widely from the fields surrounding Mathur Village in Pudukkottai District. It was authenticated by the Botany Department of Bishop Heber College, Trichy-17. The fresh leaves were washed with distilled, shade dried and coarsely powdered. This powder was mixed with the standard rat feed and $1 \% \mathrm{w} / \mathrm{w}$ level and used for the experiment. ${ }^{6}$

\section{Alcoholic Fraction}

The powdered material was then subjected to Soxlet extraction using ethanol (95\%) for 6 hs. The solvent was removed in vacuo to give an appropriate yield of $13 \%$. The residue of the ethanolic fraction was suspended in normal saline solution and fed orally to the rats at $250 \mathrm{mg} / \mathrm{kg}$ body weight. $^{7}$

\section{Tannic acid}

Pure tannic acid (analytical grade - Sigma) was suspended in normal saline and fed orally at $100 \mathrm{mg} / \mathrm{kg}$ weight concentration. ${ }^{8}$

\section{Sylimarin}

Pure Sylimarin (Sigma) was suspended in normal saline $(100 \mathrm{mg} / \mathrm{kg}$ body weight) was given orally to the rats. ${ }^{9}$

\section{Chemicals}

All biochemicals were obtained from Sigma Chemical company, Sisco Research Laboratories, Mumbai, India, Boehringer-Mannheim, Germany and British Drug House (BDH), Pvt. Ltd., Glaxo division, Mumbai, India. All chemicals, acids, bases, solvents and salts used for the investigations were of Analytical grade (AR).

\section{Experiments}

\section{Experimental Protocol}

60 rats of same age and equal weight were selected after 15 days of acclimatization, they were divided into 10 groups 6 each the animals were fed ad libitum with the respective experimental feed and water through at experimental period. All the managemental practices were followed to all animals identically except the feed and oral treatment.

Group I : Feed alone.

Group II : Feed + Aflatoxin (1ppm).

Group III : Feed + T. procumbens $(1 \%)$.

Group IV : Feed + Aflatoxin $(1 \mathrm{ppm})+T$. procumbens $(1 \%)$.

Group V : Feed + Alcoholic extract of T. procumbens $(250 \mathrm{mg} / \mathrm{kg}$ body weight).

Group VI : Feed + Aflatoxin (1 ppm)+ Alcoholic extract of T. procumbens $(250 \mathrm{mg} / \mathrm{kg}$ body weight).

Group VII : Feed+ Tannin (100 mg/kg body weight).

Group VIII : Feed+ Aflatoxin (1 ppm)+ Tannin $(100 \mathrm{mg} / \mathrm{kg}$ body weight).

Group IX : $\quad$ Feed + Sylimarin $(100 \mathrm{mg} / \mathrm{kg}$ body weight $)$.

Group X : Feed+ Aflatoxin (1 ppm)+ Sylimarin $(100 \mathrm{mg} / \mathrm{kg}$ body weight).

\section{Morphological Studies}

\section{Sampling}

Body weights of individual animals were recorded before and after the experimental period. Six rats from each treatment group were killed after 30 days along with their control group. The animals were fasted overnight, sacrificed by cervical decapitation. Liver and kidney were immediately excised; after perfusing with physiological saline, the organs were blotted dried, weighed in the electronic balance (Anamed Model 3000).

\section{Morphological Parameters}

The morphological parameters were observed, which includes body weight, liver weight and kidney weight of the alfatoxin fed animals.

\section{Haemetological Studies}

\section{Sampling}

The whole blood was collected in EDTA (anticoagulant) for haematological experiments and the serum was obtained from the clotted blood samples for biochemical studies.

\section{Haematological Parameters}

The hematological parameters such as Haemoglobin $(\mathrm{Hb}),{ }^{10}$ Red Blood Corpus Cells (RBC), ${ }^{11}$ White Blood Corpus Cells (WBC), ${ }^{12}$ Packed Cell Volume (PCV), ${ }^{13}$ Prothrombin time $(\mathrm{PT})^{14}$ were recorded eventually. 


\section{Statistical Analysis}

In the present investigation, since more than two treatment groups (ten treatment groups) have been studied, the analysis of variance (ANOVA) was carried out to test whether changes among the groups differ significantly.

Single way of analysis of variance was used to examine if significant differences existed in the haematological, biochemical changes among the different groups. A planned comparison among the means was done and the variance ratio was obtained. The entire analyses were computed with the help of SPSS Software package (12 version).

\section{RESULTS AND DISCUSSION}

\section{Changes in the Weight of Body, Liver and Kidney}

The liver and kidney body weight changes in both control and experimental animals is shown in. Figure 1a-c. The body weight of the rats

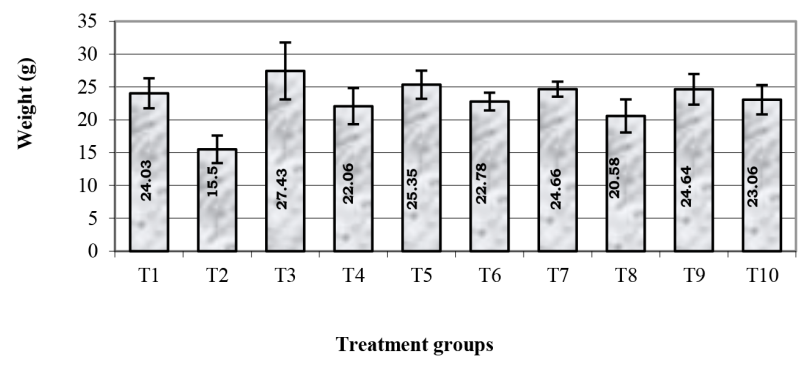

Figure 1a: Changes in the Body weight of the experimental rats.

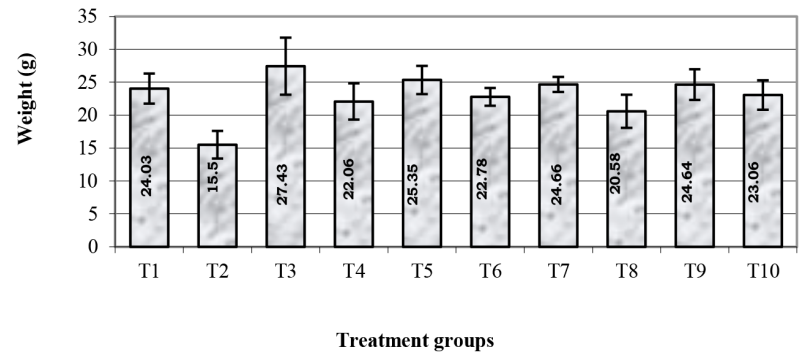

Figure $1 \mathbf{b}$ : Changes in the Liver weight of the experimental rats.

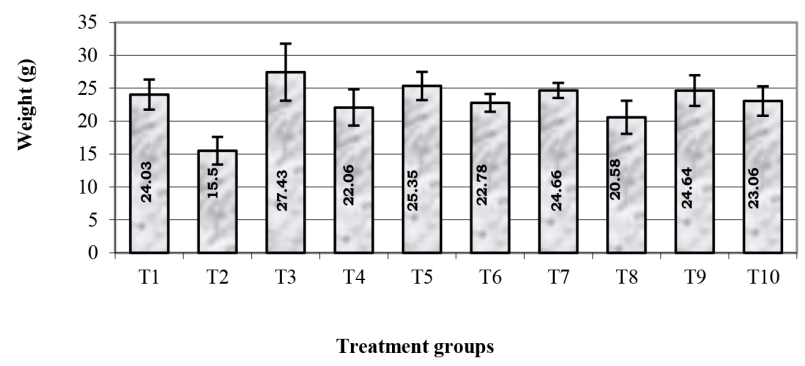

Figure 1c: Changes in the Kidney weight of the experimental rats. which declined due to the aflatoxin, recovered after treatment with each one of the drugs [T. procumbens (T4), its alcoholic extract (T6) and tannin (T8)]. The maximum recovery was found in sylimarin treated group while the minimum recovery was found in tannin. Entire plant and alcoholic extracts are equally more efficient than the individual single compound, tannin of the leaf. The control animals did not show any significant variation in the body and organ weights when compare to the drug treated animals [T. procumbens (T3), alcoholic extract (T5), tannin (T7) and sylimarian (T9)]. But among the drug treated animals, entire plant (T3) induces maximum increase in the body weight and tannin the minimum weight (T7).

Tersitore ${ }^{15}$ have shown that tumour growth elicited marked loss of body weight in growing asitic hepatoma bearing rats is shown in . This may be due to decreased food intake and/or absorption, which contribute to muscle waste in tumour. Tumour may act as nitrogen trap and the cells are more efficient in utilizing amino acids for gluconeogenesis than growth. ${ }^{16}$

Moreover the host responds to increased tumour load by decreased muscle protein synthesis and muscle break down. Amino acids resulting from breakdown are subsequently used by liver, further increasing the host metabolic burden. ${ }^{17}$ This could probably be the reason for the loss of weight due to aflatoxicosis.

In aflatoxicosis condition, the weight of liver and kidney (not significant) decrease largely due to protein degradation during tumour growth. Protein metabolic perturbations in host, although causing tissue waste may themselves favour the growth of tumour itself.

The recovery in the body weight of Tridax and its alcoholic extract treated rats may be due to antiaflatoxicosis potency of $T$. procumbens. All the drugs causes disappearance of troublesome symptoms by subjective improvement. Absence of significant variation among the various experimental animals reveals the non-toxic nature of these drugs. A similar observation has been noted in the body and organ weight gain at the optimum dose of Tridax. ${ }^{18}$

\section{Hematological Parameters}

Table 1 shows the levels of haemoglobin, RBC, WBC, PT and PCV in the control and experimental groups of rats. Increased $\mathrm{RBC}$ and $\mathrm{WBC}$ counts and increased levels of haemoglobin and PCV, in the T. procumbens, its extract and tannin treated groups, indicate the protective effects of the plant and its extract on the haemopoietic system. Tannin induces the maximum recovery in all the haematological parameters (Haemoglobin, RBC, WBC, Prothrombin and PCV). Alcoholic extract brings about the maximum recovery except in haemoglobin. The proven hepatoprotective agent (sylimarin) was next in its recovery efficiency in all the haematological parameters studied.

The blood cells are the mobile units of the body's protective system. ${ }^{19}$ Decreased white blood count $(\mathrm{p}<0.001)$ in the aflatoxin fed animals indicate decreased resistance of the body to toxicity induced by $\mathrm{AFB}_{1}$. Decreased RBC count $(\mathrm{p}<0.001)$, haemoglobin $(\mathrm{p}<0.001)$ and PCV $(\mathrm{p}<0.001)$ also indicate the severity of hepatic damage induced by $\mathrm{AFB}_{1}$. Decrease in the haemoglobin levels might be due to increased catabolism and degradation of haemoglobin to bilirubin. Reduction in $\mathrm{Hb}$ content can be related to decrease in RBC number which in turn indicates anaemic induction. ${ }^{20}$ Induction of anaemic status in toxicity and cancer are well established. A mild degree of anaemia is one of the complications observed in HCC patients. ${ }^{21}$ Increased RBC and WBC contents and increase levels of haemoglobin and PCV in the drug treated groups along with the toxin indicate the protective effect of the plant and its extract on the haemopoietic system.

The PT was significantly $(\mathrm{p}<0.001)$ prolonged in the aflatoxin fed animals as compared to control animals. This reflects the defects in the intrinsic 


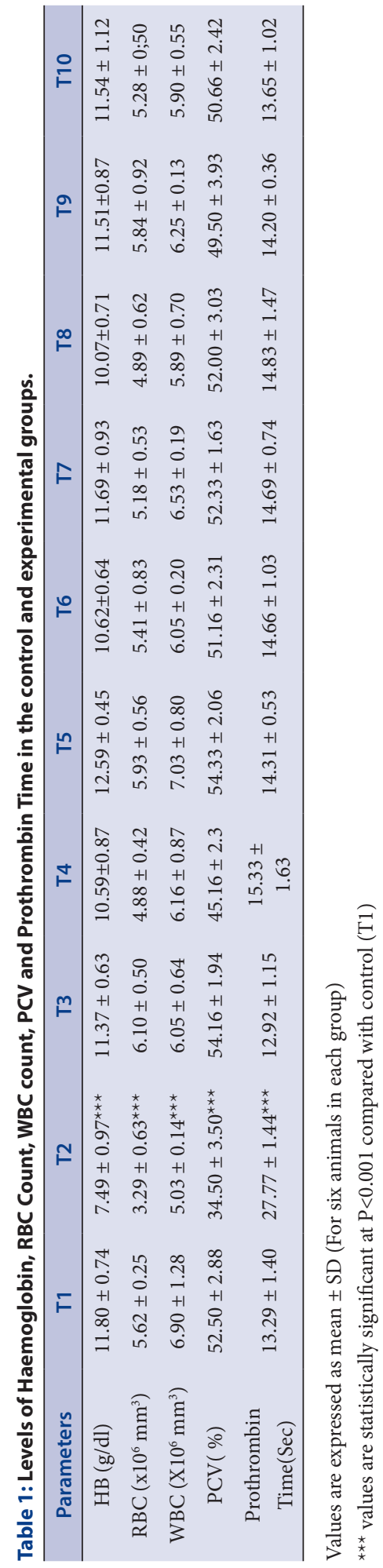

and extrinsic pathways of coagulation system due to $\mathrm{AFB}_{1}$ administration. PT measures the rate at which prothrombin is converted to thrombin in the presence of thromboplastin, calcium, fibrinogen and other coagulation factors. The prolongation of PT in the aflatoxico rats might be due to the fact that the liver may be damaged and that it cannot adequately synthesize the clotting factors. ${ }^{22}$ Previous reports have showed prolonged partial thromboplastin time in liver diseases according to the degree of hepatic failure. ${ }^{23}$

The PT was significantly $(\mathrm{p}<0.001)$ decreased in the $T$. procumbens, its alcoholic extract and tannin treated group of rats as compared to aflatoxin fed group of rats. This indicates the ability of plant and its extract to correct the defects in the intrinsic and extrinsic pathways of the coagulation system.

\section{CONCLUSION}

From the above observations, it can be concluded that the organ and body weight of the animal declined due to the aflatoxin and it increased on treatment with of T. procumbens in the extracts of aqueous, alcoholic extracts. The recovery of body weight on treating with T. procumbens is due to its antiaflatoxicosis potency.The RBC, WBC counts, haemoglobin levels and PCV were observed to increase in T. procumbens, its extract and tannin treated groups whereas the PT has been found be decreased in T. procumbens, its extract and tannin treated groups when compared to aflatoxin fed group of experimental animals.

\section{ACKNOWLEDGEMENT}

The Authors thank the Head, Department of Botany, Bishop Heber College, Tiruchirappalli for providing the facilities.

\section{CONFLICT OF INTEREST}

There is no conflict of Interest.

\section{ABBREVIATION USED}

PT: Prothrombin time; WBC: White Blood Corpus Cell; RBC: Red Blood Corpus Cell; PCV: Packed Cell Volume.

\section{REFERENCES}

1. Bhagwat DA, Killedar SG, Adnaik RS. Anti-diabetic activity of leaf extract of Tridax procumbens. Int J Green Pharm. 2008;2(2):126-8.

2. Patel NS, Jain DK, Nagar $H$, Patel A, Chandel HS. Evaluation of analgesic and antipyretic activity of Tridax procumbens leaves extract. RGUHS J Pharm Sci. 2011;1(3):226-31.

3. Salahdeen HM, Yemitan OK, Alada AR. Effect of aqueous leaf extract of Tridax procumbens on blood pressure and heart rate in rats. Afr J Biomed Res. 2004; $7(1): 27-9$.

4. Shotwell OL, Herseltine CW, Subblefield RD, Sorenson GW. Production of aflatoxin on rice. Appl.Microbiol. 1966;14(3):425-8.

5. Romer S. Qualitative/quantitative analysis for detection and estimation of aflatoxin (Romer mini column method) J. Asso. Off. Anal. Chem. 1975;58:500-6.

6. Kumar S, Asokan D, kumar SP, Kalavathy S, Manoharan N. Salubrious effect of Tridax procumbens on paracetamol hepatotoxicity. Indian J. of Pharmceutical. Sci. 2001;63(1):64.

7. Saraf S, Dixit VK. Hepatoprotective activity of Tridax procumbens- Part II, Fitoteratia. 1991;62(6):534-5.

8. Shanmugasundaram A. The Efficiency of Tannic acid in curing Liver Damage due to Mycotoxin. A M.Sc, thesis submitted to the Bharathidasan University, Tiruchirapalli, Tamil Nadu, India. 200.

9. Girish S, Achiliya G, Sudhir, Wadodar, Avinash, Dorle K. Evaluation of heptoprotective effect of Amalkadi ghrita against $\mathrm{CCl}_{4}$ induced hepatic damage in rats. J Ethanopharmacology. 2004;90(2):229-32.

10. Drabkin DL, Austin JH. Spectrophotometric studies. Spectrophotometric constants for common haemoglobin derivatives in human, dog and rabbit blood. J Biol Chem. 1932;98(2):719-33

11. Huxtable RJ. Activation and pulmonary toxicity of Pyrrolizadine alkaloids Phar- 
macol. Ther, 1990;47(3):371-89.

12. Raghuramulu N, Nair KM, Kalyanasundaram S. In: "A manual of laboratory techniques", Silver prints, Hydrabad. 1983;254.

13. Wintrobe MM. The size and haemoglobin content of the erythrocyte: methods of determination and clinical applicatuion. J Lab Clin Med. 1932;17:889

14. Mukherjee KL. Medical laboratory technology, Tata Mc Graw Hill Pub. Co., Ltd. 1988; 1.

15. Tersitore L, Bonelli G, Baccino FM. Early development of protein metabolic perperbation in the liver and skeletoal miscle of tumours leasing rats Biochem. 1987;241(1):153-9.

16. Shelman CD, Mortan JJ, Mider GB. Potential source of Tumour nitrogen cancer Res.1950;10:374-8.

17. Waterhouse C, Jean-pretre N, Keilson J. Gluconeogenesis from alanine in patients with progressive malignant disease, cancer Res. With progressive malignant disease. Cancer Res. 1979;39(6 Part 1):1968-72.

18. Susila Appadurai. The efficacy of Tridax procumbens L. in Ameliorating aflatoxicosis in hybrid broiler chicken, Cobb 2000. A Ph.D thesis submitted to Bharathidasan University, Tiruchirapalli, Tamil Nadu, India. 2001.

19. Guyton AC, Hall JE. Text book of medical physiology, $10^{\text {th }}$ edition WB Saunder's Company, Philadelphia PA. 1991;8:801-15.

20. Sarantchandra GJ,Chandre S, Jayasuder, Murthy PB. Toxicology of cleistanthus collinus an indigeneous plant acute toxicity study. Indian J Toxicol. 1996;3:9-17.

21. Murrary-Lyon IM. Primary and secondary causes of the liver. In: carcinoma of the liver, billiary tract and pancrease, Genet J.C (ed). Edward, Arnold Ltd. Bed for square, London.1983.

22. Johnson PJ. The assessment of hepatic function and investigation of jaundice. In: Marshall WJ, S.K.Bangers (eds). Clinical Biochemistry: Metabolic and clinical aspects, Churchill livingstone, New York. 1995;217-36.

23. Denninger MH. Haemostasis in liver disease. In: Bircher J, J.P.Benhamou, N.Mc Intyre, M.Rizzetto and J. Rodes (eds). Clinical hepatology, oxford university press New York. 1999;1795-815.

\section{GRAPHICAL ABSTRACT}

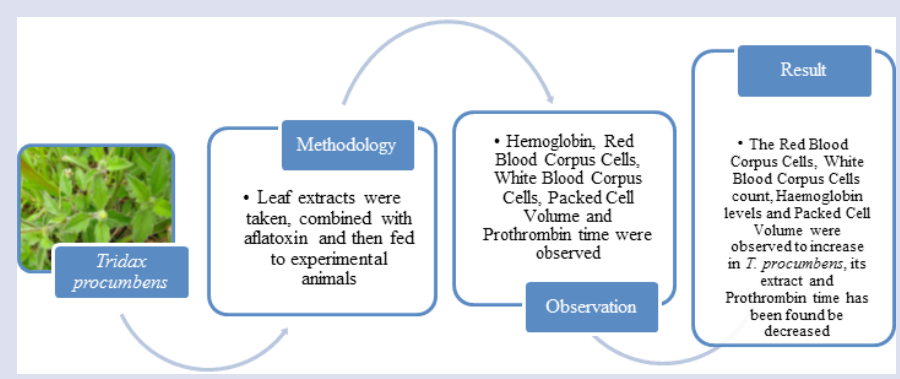

ABOUT AUTHORS

\section{SUMMARY}

- Leaf extracts of Tridax procumbens were taken, combined with aflatoxin and then fed to experimental animals to study the Hematological parameters such as Hemoglobin, Red Blood Corpus Cells, White Blood Corpus Cells, Packed Cell Volume and Prothrombin time.

- The Red Blood Corpus Cells, White Blood Corpus Cells count, Haemoglobin levels and Packed Cell Volume were observed to increase in T. procumbens, its extract and PT has been found be decreased.

- $\quad$ From the above results, we concluded that T. procumbens have an anti-aflatoxicosis potency.

Palanisamy Sampathkumar: Department of Chemistry and Biosciences, SASTRA Deemed University, SRC campus, Kumbakonam, Tamil Nadu, INDIA. His area of research includes Clinical Biochemistry and Phytopharmocology.

Cite this article: Sampathkumar P, Kalavathy S, Anand AV, Sangeetha T, Sujeetha P. Impact of Tridax procumbens on Hematological Parameters in Aflotoxin Induced Liver Toxicity in Albino Rats. Pharmacog J. 2018;10(2):304-8. 